\title{
PRODUÇÃO DE HIBRIDOMAS SECRETORES DE ANTICORPOS ANTI- Neospora caninum PARA USO EM IMUNODIAGNÓSTICO
}

\author{
Bruna Alves DeVens ${ }^{1}$, MARlene Isabel VARgas VIloria ${ }^{2}$, CARlos HenryQue de Souza E \\ SILVA $^{3}$, JOAQUIN HERNÁN PATARROYO SALCEDO ${ }^{2}$ \\ ${ }^{1}$ Professora Mestre do Centro Universitário do Espírito Santo, Colatina, ES, Brasil - brudevens@ @otmail.com \\ ${ }^{2}$ Professores Doutores da Universidade Federal de Viçosa, Viçosa, MG, Brasil. \\ ${ }^{3}$ Pós-Doutorado, Universidade Federal de Ouro Preto, Ouro Preto, MG, Brasil.
}

\begin{abstract}
O Neospora caninum é um protozoário apicomplexa com maior implicação em abortamentos em muitos países do mundo. As perdas econômicas determinadas pela neosporose incluem além dos abortamentos também o descarte precoce de vacas, os custos de reposição de novos animais no rebanho, a queda na produção leiteira, bem como na produção da gordura no leite. O diagnóstico imunológico envolve a aquisição de kits diagnósticos existentes no mercado os quais apresentam alto custo. Portanto, o objetivo do presente trabalho foi à produção de hibridomas secretores de anticorpos policlonais com afinidade ao Neospora caninum (cepa Nc-1) para utilização em imunodiagnósticos. Para a produção dos
\end{abstract}

anticorpos usou-se o protozoário sonicado, proveniente da cultura em células VERO, que foi purificado por filtração. Esses taquizoítos foram utilizados na imunização dos camundongos BALB/c, usando-se como adjuvante a saponina, o que permitiu a obtenção de anticorpos policlonais capazes de revelar a fluoresceína na reação da imunofluorescência indireta. A fusão das células esplênicas, provenientes dos camundongos imunizados com as células de mieloma SP2/0 resultou na obtenção de $72,4 \%$ de hibridomas secretores de anticorpos anti-Nc-1. Esses hibridomas secretaram anticorpos positivos ao $N$. caninum e negativos ao Toxoplasma gondii.

PALAVRAS-CHAVE: anticorpos monoclonais, diagnóstico imunológico, hibridomas, neosporose.

\section{PRODUCTION OF HYBRIDOMAS SECRETING ANTI-Neospora caninum ANTIBODIES FOR USE IN IMMUNODIAGNOSTIC}

\section{ABSTRACT}

The Neospora caninum is a protozoan Apicomplexa with greater involvement in abortions worldwide. The economic losses determined by neosporosis also include abortions besides the early disposal of cows, costs for replacing animals in the herd, drop in milk production as well as milk in fat production. The immunological diagnosis involves purchasing costly diagnostic kits on the market. Therefore, the aim of this study was the production of hybridomas secreting polyclonal antibodies with affinity to Neospora caninum ( $\mathrm{Nc}-1$ strain) for immunodiagnostic use. For antibodies production, we used sonicated protozoa from Vero cells in culture, purified by filtration. These tachyzoites were employed for immunization of BALB / c mice using saponin as adjuvant, which allowed obtaining polyclonal antibodies capable of revealing fluorescein reaction in indirect immunofluorescence. The fusion of splenic cells, from the immunized mice with myeloma cells SP2 / 0 resulted in $72.4 \%$ hybridomas secreting anti-Nc-1antibodies. These hybridomas secreted antibodies positive to $N$. caninum and negative to Toxoplasma gondii.

KEYWORDS: hybridomas, immunodiagnosis, monoclonal antibodies, neosporosis. 


\section{INTRODUÇÃO}

Neospora caninum é um protozoário que foi reconhecido em cães por Bjerkas et al. ${ }^{1}$, ao descreverem a ocorrência de uma enfermidade neurológica em filhotes de cães da Noruega caracterizada por encefalomielite, miosite $\mathrm{e}$ paresia. Parasitos livres foram encontrados no cérebro e nos músculos e formas encistadas no cérebro dos cães acometidos pela enfermidade. As formas encistadas assemelhavam-se à Toxoplasma gondii, porém, os testes sorológicos realizados para este parasita apresentaram-se negativos.

Dubey et al. ${ }^{2}$ tornaram a analisar os cortes histológicos dos 23 cães mortos em 1984, os mesmos estudados por Bjerkas et al. ${ }^{1}$, e observaram que 13 dos 23 animais tiveram diagnóstico confirmado para $T$. gondii, enquanto nos outros 10 cães identificaram-se um novo gênero que foi denominado de Neospora com a descrição de uma nova espécie. Os sinais clínicos relacionados à infecção por Neospora nesses cães foram a paresia e a paralisia dos membros pélvicos, sintomatologia não observada na toxoplasmose ${ }^{2}$.

Furuta et al. ${ }^{6}$ demonstraram que cães excretaram oocistos através das fezes após serem alimentados com ovos embrionados infectados experimentalmente com taquizoítos de $N$. caninum. Costa et al. ${ }^{7}$ encontraram soroprevalência em aves infectadas naturalmente $(1,5 \%$ das galinhas criadas intensivamente e $23,5 \%$ das criadas extensivamente), indicando que possuem um importante papel na epidemiologia no meio rural. A presença de cães, aves domésticas, silagem e fornecimento de colostro foram fatores de risco observados em rebanhos bovinos leiteiros com ocorrência de abortos associados ao $N$. Caninum $^{8}$.

Como agente patogênico para bovinos, $N$. caninum foi indicado inicialmente por Thilsted e Dubey $^{3}$ e, desde então, vem sendo associado a prejuízos econômicos consideráveis para a pecuária de corte e leite em diversos países. Os principais prejuízos econômicos relacionam-se ao abortamento e à mortalidade neonatal em bovinos ${ }^{4}$, porém os bezerros podem apresentar sintomatologia nervosa logo após o nascimento, devido às lesões inflamatórias do sistema nervoso central, ou serem clinicamente normais, mas cronicamente infectados, devido à transmissão transplacentária ${ }^{5}$.

Uma das provas diagnósticas mais utilizadas para a neosporose fundamenta-se em ensaios imunoenzimáticos (Enzyme-Linked Immunosorbent Assay/ELISA), que têm sido amplamente utilizados na confirmação das infecções em rebanhos bovinos devido à sua rapidez e facilidade para a análise dos resultados ${ }^{9}$.

Conforme indicado por Lenaars e Hendriksen ${ }^{10}$, anticorpos têm sido amplamente utilizados para detecção e caracterização imunoquímica de diversos componentes celulares, assim como em testes imunodiagnósticos e na identificação de patógenos relacionados com doenças humanas e animais, entre outros usos. Nesse contexto, produção de células híbridas imortalizadas em culturas de tecido e produtoras de anticorpos com especificidade pré-determinada pelo processo de sua preparação, conhecido como hibridomas secretores de anticorpos, são de grande interesse biotecnológico ${ }^{10}$.

A produção de anticorpos monoclonais para a caracterização de componentes moleculares antigênicos de N. caninum envolvidos no processo de invasão celular é importante para o desenvolvimento tanto de ferramentas de diagnóstico como para o controle da infecção nos hospedeiros.

Assim, buscando a obtenção de novos insumos biotecnológicos, buscou-se, neste estudo, a produção de hibridomas secretores de anticorpos contra proteínas de taquizoítos do $N$. caninum direcionada à utilização para o imunodiagnóstico da neosporose.

\section{MATERIAL E MÉTODOS}

O presente estudo foi conduzido no Laboratório de Biologia e Controle de Hematozoários e Vetores (LBCHV) no Instituto de Biotecnologia Aplicado à Agropecuária (BIOAGRO) e biotério do Departamento de Educação Física, na Universidade Federal de Viçosa (UFV).

A cepa $\mathrm{Nc} 1$ isolada de cão $^{2}$, foi cedida pelo departamento de Medicina Veterinária da Universidade Federal da Bahia. Realizou-se a multiplicação do $N$. caninum em células VERO que foram mantidas em meio de cultivo (RPMI 
1640 suplementado com $10 \%$ de Soro Fetal Bovino) em garrafas de cultura dispostas em estufa a $37^{\circ} \mathrm{C}$ e $5 \%$ de $\mathrm{CO}_{2}$. Após 96 horas da inoculação foram coletados os taquizoítos por raspagem da garrafa. Os taquizoítos foram lavados a $1000 \mathrm{~g} / 10$ minutos com PBS pH 7,2 e purificados por filtração em membrana $5 \mu \mathrm{m}$ (Millipore ${ }^{\circledR}$ ). $\mathrm{O}$ pellet foi ressuspendido em PBS pH 7,2 e os taquizoítos de $N$. caninum contados em câmara de Newbauer. Para a realização da reação de imunofluorescência indireta (RIFI), $10^{3}$ taquizoítos íntegros de $N$. caninum produzidos na etapa descrita anteriormente foram adicionados às lâminas de vidro em um volume de $10 \mu \mathrm{L} /$ poço e fixados com metanol.

Os taquizoítos purificados do $N$. caninum foram descongelados e aliquotados para a inoculação dos camundongos do grupo que recebeu os taquizoítos íntegros, sendo mantidos em gelo até o momento da inoculação. Para o preparo das amostras de taquizoítos sonicados, os mesmos foram descongelados rapidamente em banho-maria a $37{ }^{\circ} \mathrm{C}$, sonicados a 200 Watts/30 segundos e colocados em nitrogênio líquido por $10 \mathrm{~min}$ e novamente em banho-maria, sendo este ciclo repetido quatro vezes. As amostras sonicadas foram mantidas em gelo até o momento da inoculação dos animais. A dosagem protéica das amostras foi realizada pelo método de Bradford.

Os camundongos $\mathrm{BALB} / \mathrm{c}$ foram inoculados com quatro doses de inóculo contendo $50 \mu \mathrm{g}$ de taquizoítos de $N$. caninum, $50 \mu \mathrm{L}$ de adjuvante saponina e $100 \mu \mathrm{l}$ de PBS (via subcutânea). Os animais foram inoculados com intervalos de 21 dias entre cada aplicação. As amostras do soro sanguíneo foram coletadas antes e após as inoculações para a avaliação dos títulos de anticorpos anti- $N$ caninum e anti- $T$. gondii dos camundongos através da reação de imunofluorescência indireta (RIFI). Por meio do cálculo de $\mathrm{C}$ (concentração) $=\mathrm{m} / \mathrm{v}$ (massa/volume), concluiu-se que era preciso a utilização de $36 \mu \mathrm{L}$ da suspensão dos taquizoítos íntegros e $46 \mu \mathrm{L}$ da suspensão dos taquizoítos sonicados, para que cada animal de ambos os grupos recebessem a mesma massa de antígenos

Os esplenócitos, de camundongos BALB/c inoculados com $N$. caninum e positivos a este parasita, foram fusionados a células de mieloma SP2/0 (cedidas pelo laboratório de Imunologia da Universidade Federal da Bahia), em uma proporção de $10^{8}$ linfócitos para $10^{7}$ mielomas. As células fusionadas foram colocadas em microplacas de microtitulação de 96 poços e incubadas a $37{ }^{\circ} \mathrm{C}$ e $5 \%$ de $\mathrm{CO}_{2}$ em meio RPMI1640, sendo suplementadas com meio HAT (hipoxantina, aminopterina, timidina). Após 15 dias da fusão, as células foram suplementadas com meio HT (hipoxantina, timidina e glicina) e o sobrenadante foi coletado para a realização da RIFI.

A fim de detectar a presença de anticorpos anti- $N$. caninum e sua possível reação cruzada com T. gondii, foi realizada a reação de imunofluorescência indireta (RIFI) com os sobrenadantes das culturas dos híbridos. Os sobrenadantes da cultura celular foram adicionados às lâminas e incubados em câmara úmida a $37{ }^{\circ} \mathrm{C}$ por duas horas. As lâminas foram lavadas e adicionou-se o conjugado IgG de coelho anti-camundongo conjugado com isotiocianato de fluoresceína (FIT, Sigma ${ }^{\circledR}$, CAS number 3326-327) na diluição 1:64. Após a incubação, as lâminas foram analisadas em microscópio de imunofluorescência. Os hibridomas positivos ao $N$. caninum e negativos ao $T$. gondii foram submetidos à expansão em placas de microtitulação de 6 poços, e os sobrenadantes contendo os anticorpos secretados pelos híbridos foram congeladas a $-70{ }^{\circ} \mathrm{C}$. Após a seleção dos híbridos produtores dos anticorpos contra o $N$. caninum, eles foram expandidos para obtenção de um número suficiente de híbridos para uma posterior clonagem. Anteriormente ao processo de expansão, preparou-se, com 24 horas de antecedência, uma monocamada de macrófagos.

Os procedimentos experimentais utilizando os animais em laboratório foram realizados de acordo com as normas de experimentação animal definidas pelo Colégio Brasileiro de Experimentação Animal (COBEA) e com a legislação vigente, tendo sido aprovado pela Comissão de Ética do Departamento de Medicina Veterinária da Universidade Federal de Viçosa (DVT/UFV), sendo certificado pelo processo de $n^{\circ}$ $17 / 2008$.

\section{RESULTADOS E DISCUSSÃO}

A concentração das proteínas dos parasitos íntegros foi determinada em $1392 \mu \mathrm{g} / \mathrm{mL}$ e os parasitos sonicados em $1108 \mu \mathrm{g} / \mathrm{mL}$, como se observa na Tabela 1. 
Tabela 1 - Concentração protéica do Neospora caninum mantido íntegro e o sonicado.

Amostra Absorvância Concentração Protéica $(\mu \mathrm{g} / \mathrm{mL})$

$\begin{array}{llr}\text { Parasito íntegro } & 0,234 \mathrm{AU} & 1392 \mu \mathrm{g} / \mathrm{mL} \\ \text { Parasito sonicado } & 0,179 \mathrm{AU} & 1108 \mu \mathrm{g} / \mathrm{mL}\end{array}$

Diante dos resultados apresentados, foi possível definir o volume de cada inóculo a ser aplicado nos camundongos, já que cada animal foi submetido a $50 \mu \mathrm{g}$ de massa parasitária. A dosagem do imunógeno a ser inoculada nos animais seguiu a mesma determinação de Schunk e Macallum $^{11}$. Verificou-se que o parasita sonicado obteve menor concentração de proteínas, pelo fato de antígenos terem ficado ligados às membranas e algumas proteínas terem sido destruídas com a realização da sonicação ${ }^{11}$.

Os animais que receberam os taquizoítos rompidos tornaram-se infectados, confirmando os dados obtidos por Omata $^{12}$, que demonstraram resposta imune mais evidente no grupo que recebeu os taquizoítos rompidos do que no grupo que recebeu os taquizoítos íntegros. $\mathrm{O}$ animal que teve maior número de taquizoítos fluorescentes foi eleito para a coleta do baço para a realização da fusão dos esplenócitos com os mielomas.

Da fusão realizada com o baço deste animal positivo, observou-se que $72,4 \%$ dos híbridos, testados pela RIFI, produziram anticorpos anti- $N$. caninum, como se verifica na Tabela 02. Dessa porcentagem, foram escolhidos os 50 melhores hibridomas que apresentaram bom crescimento celular, os quais foram congelados a $-70{ }^{\circ} \mathrm{C}$.

A utilização da monocamada de macrófagos na cultura dos hibridomas demonstrou ser benéfica quando comparados os crescimentos dos híbridos cultivados em placas com sua presença ou ausência, pois houve estímulo do crescimento dos híbridos e a promoção da limpeza das culturas, o que confirma os fatos relatados por Souza ${ }^{13}$.

Realizou-se o congelamento dos híbridos em todas as etapas consideradas de risco, a fim de se evitarem perdas de material, além da sua manutenção em amostras para estudos posteriores.

A escolha dos híbridos também foi baseada na capacidade de multiplicação das células e na sua viabilidade, o que foi observado nos híbridos $3 \mathrm{H} 8$, 2A2, 2G2, 1E1, conforme se observa na Figura 01.

Além disso, os híbridos foram prioritariamente selecionados por serem positivos para $N$. caninum e negativos para $T$. gondii por meio da realização da RIFI, conforme observado na Figura 2. Isso foi necessário para se observar a existência da reação cruzada entre esses dois parasitas, garantindo, dessa forma, a secreção de anticorpo com afinidade ao $N$. caninum, com o mesmo objetivo de $D_{\text {ubey }}^{2}$ e Souza ${ }^{13}$.

As técnicas desenvolvidas possibilitaram a preservação dos hibridomas anti- $N$. caninum no Brasil, possibilitando ao LBCHV da UFV a utilização dos hibridomas para trabalhos posteriores, assim como foi realizado por Souza ${ }^{13}$.

Tabela 02- Comparação por porcentagem entre o número dos híbridos positivos e negativos utilizando-se a técnica de imunofluorescência indireta ao Neospora caninum

\begin{tabular}{ccccc}
\hline Placas & 1 & 2 & 3 & Total \\
\hline Positivos & $70,6 \%$ & $80,0 \%$ & $58,4 \%$ & $72,4 \%$ \\
Negativos & $29,4 \%$ & $20,0 \%$ & $41,6 \%$ & $27,6 \%$ \\
\hline
\end{tabular}




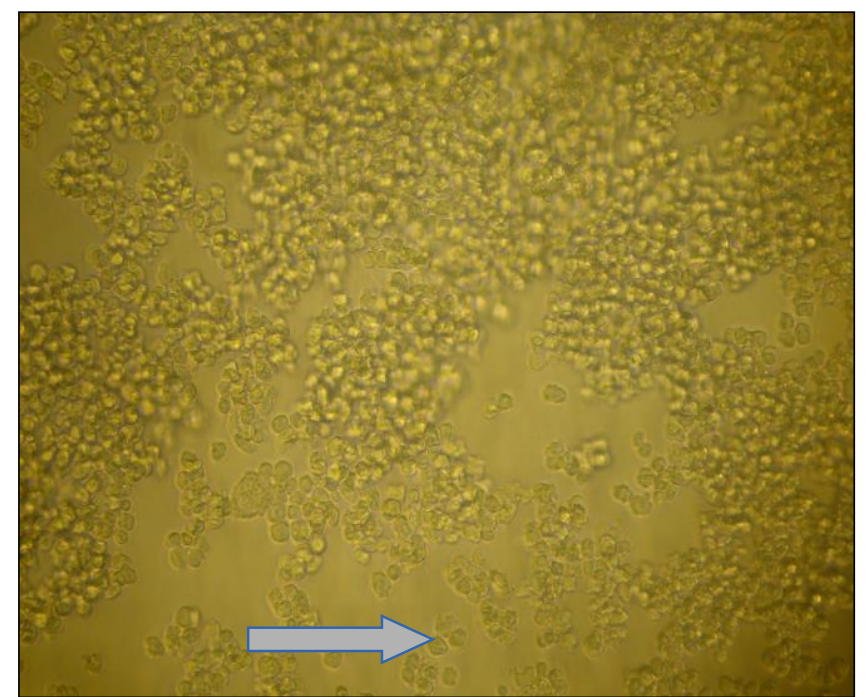

Figura 01. Demonstração do Poço 2G2, da placa de 96 pocinhos com híbridos viáveis, na ponta da seta é possível observar a integridade celular.

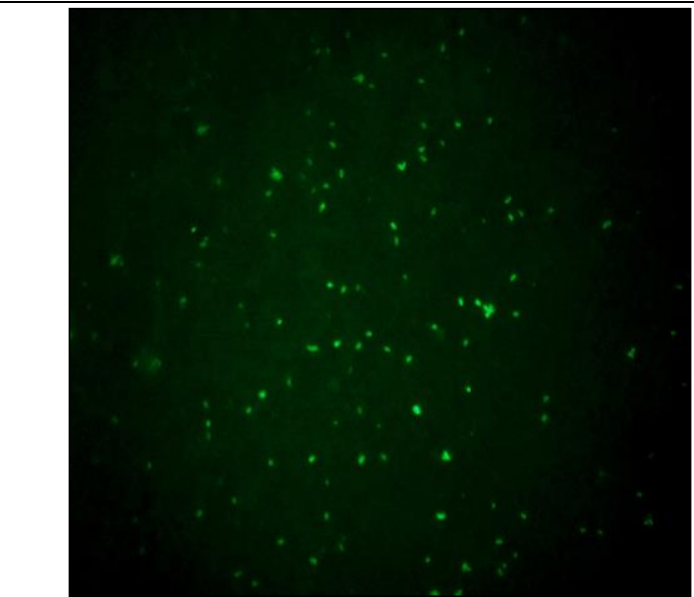

(a)

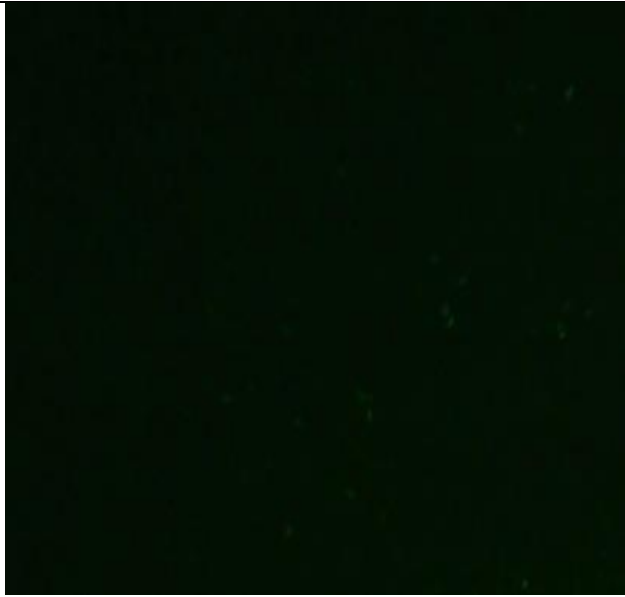

(b)

Figura 02. Resultado da Imunofluorescência Indireta 200x. (a) Resultado positivo ao Neospora caninum do híbrido 3H8; (b) Resultado negativo ao Toxoplasma gondii do híbrido 3H8.

\section{CONCLUSÃO}

A imunização dos camundongos com o $N$. caninum purificado e sonicado permitiu a obtenção de anticorpos policlonais capazes de detectar a proteína parasitária nos ensaios do tipo RIFI. A produção dos hibridomas secretores de anticorpos policlonais que reconheceram o $N$. caninum por RIFI e foram negativos ao $T$. gondii mostra-se como uma metodologia indicada para produção de insumo de imunodiagnósticos para a neosporose.

\section{AGRADECIMENTOS}

À CAPES, CNPq e FAPEMIG pelo apoio financeiro $\mathrm{e}$ bolsas concedidas para $\mathrm{o}$ desenvolvimento do estudo realizado.

\section{REFERÊNCIAS}

1. Bjerkas I, Mohn SF, Presthus J, Unindentified cystforming sporozoon causing encephalomyelitis and myositis in dogs. Z Parasitenkunde, 1984;70:271-274.

2. Dubey JP, Carpenter JL, Speer CA, Topper MJ, Uggla A, New recognized fatal protozoan disease of dogs. J Am Vet Med Assoc, 1988;192:1269-1285.

3. Thilsted, J.P.; Dubey, J.P. Neosporosis - Like Abortions in a Herd of Dairy Cattle. J Vet Diagn Invest, 1989;1:205-209.

4. Jenkins M, Baszler T, Björkman C, Schares G, Williams D. Diagnosis and seroepidemiology of Neospora caninum-associated bovine abortion. In J Parasitol. 2002 $32(5): 631-6$

5. Dubey, J.P., Lindsay, D.S. A review of Neospora caninum and neosporosis. Vet Parasitol, 1996; 67:1-59. 
6. Furuta, P.I.; Mineo, T.W.; Carrasco, A.O.; Godoy, G.S.; Pinto, A.A.; Machado, R.Z. Neospora caninum infections in chicken and embryonated eggs. Parasitol, 2007;134:1931-1939.

7. Costa KS, Santos SL, Uzêda, RS, Pinheiro AM, Almeida Mao, Araújo FR, McAllister, MM, Gondim, LFP. Chickens (Gallus domesticus) are natural intermediate hosts of Neospora caninum, Int J Parasitol, 2008; 38:157-159.

8. Corbellini LG, Smith DR, Pescador CA, Schmitz M, Correa A, Steffen DJ, Driemeier, D. Herd-level risk factors for Neospora caninum seroprevalence in dairy farms in southern Brazil. Prev Vet Med, Amsterdam, 2006; 74(2-3):130-14.

9. Wright, P.F.; Nilsson, E.; Van Rooij, E.M.A. Standardization and validation of enzyme-linked immunosorbent assay techniques for the detection of antibody in infectious disease diagnosis. Rev Sci Tech,
1993;12(2):4435-4450.

10. Leenaars, M; Hendriksen, F.M. Critical steps in the production of polyclonal and monoclonal antibodies: evaluation and recommendations. ILAR J, 2005; 46(3):269-279.

11. Schunk MK, Macallum GE. Applications and optimization of immunization procedures. ILAR Journal. 2005;46(3):241-257.

12. Omata Y, Kamiya H, Kano R, Kobayashi Y, Maeda R, Saito, A. Footpad reaction induced by Neospora caninum tachyzoite eextract in infected BALB/c mice. Veterinary Parasitology, 2006;139:102-108.

13. Souza, VF. Caracterização de amostras de herpesvírus tipo 1 (BHV-1) e 5 (BHV-5) com anticorpos monoclonais. Pesquisa Veterinária Brasileira, 2002;22:13-18.

Protocolado em: 11 mar. 2013. Aceito em: 18 mar. 2014 